\title{
FACTORS THAT CONTRIBUTE TO THE USE OF MODULARISATION IN THE AUTOMOTIVE INDUSTRY: A SURVEY IN BRAZIL
}

\author{
M.A. Sellitto ${ }^{1 *}$, F.L. Nunes ${ }^{2}$ \& D.R.F. Valadares 3
}

\section{ARTICLE INFO}

Article details

Submitted by authors 16 Mar 2018 Accepted for publication 11 Sep 2018 Available online $\quad 10 \mathrm{Dec} 2018$

Contact details

* Corresponding author sellitto@unisinos.br

Author affiliations

1 Production and Systems Engineering Graduate Program, UNISINOS, São Leopoldo, Brazil

2 Technological Sciences Institute at FEEVALE, Novo Hamburgo, Brazil

3 Management Sciences Department at PUCRS, Porto Alegre, Brazil

DOI

http://dx.doi.org/10.7166/29-4-1946

\section{ABSTRACT}

This article aims to verify factors that can contribute to the use of modularisation in the Brazilian automotive industry through a survey methodology, using principal component analysis and structural equation modelling by partial least squares as techniques. We found three types of factors appearing as drivers or precursors of a formal strategy of modularisation: the use and knowledge of individual non-integrated aspects of modularisation, such as modular architecture; the introduction of competition differentials focusing mainly on cost reduction and increase in flexibility, quality, and dependability; and the existence of a business environment prone to innovation. The main conclusion is that elements of modularisation in the design and the need to meet customers' requirements have much more influence in stimulating a formal, articulated modularisation strategy than a business environment prone to innovation.

\section{OPSOMMING}

Hierdie artikel het as doelstelling die verifiëring van faktore wat kan bydra tot die gebruik van modularisering in die Brasiliaanse voertuig industrie. 'n Peilingsmetodologie, wat van vernaamste komponent-analise en strukturele vergelykingmodellering deur parsiële minste vierkante gebruik maak, word hiervoor gebruik. Drie soorte faktore is identifiseer as die voorlopers van 'n formele strategie vir modularisering, naamlik: die gebruik en kennis van individuele, nie-geïntegreerde aspekte van modularisering, soos modulêre argitektuur, die bekendstelling van kompetisie onderskeidings wat hoofsaaklik fokus op kostebesparing en 'n toename in buigsaamheid, gehalte en betroubaarheid, en die bestaan van 'n besigheidsomgewing geneig tot innovasie. Die gevolgtrekking is dat elemente van modularisering in die ontwerp en die behoefte om kliënte se versoeke te bevredig 'n groter invloed het in die stimulasie van 'n formele, geartikuleerde modularisering strategie as die besigheidsomgewing wat neig tot innovasie.

\section{INTRODUCTION}

Continuous innovation processes allow the creation and maintenance of a competitive advantage in an industry, especially if the innovation processes embrace the entire life cycle of an industrial product [1-4]. In life cycle analysis, one of the main aspects is the architecture of the product [58]. Modular architecture products usually have longer life cycles than fixed architecture ones [9,10] as, with a modular architecture, companies do not need to develop new products for new demands $[11,12]$. The product acquires new functionalities by adding new modules and not by an entirely new development $[11,13,14]$.

Researchers on innovation processes report that modularisation of products and processes can emerge due to innovation initiatives [15-18]. Studies emphasise that, when companies search for 
innovative integrated solutions for products and processes, one of the alternatives is the use of modular architecture in the products $[4,19,20]$. They also point out that modularisation can accelerate product development processes $[14,21,22]$ and increase manufacturability, which means designing products that are easier to manufacture $[13,14,18,20]$. Modularisation can also be helpful in meeting markets with characteristics of mass customisation [23-26].

A modularisation strategy can become an important part of a wider production strategy that relies on new products and innovative techniques to create competitive advantages in an industry $[15,17,27-29]$. Modularisation allows allying partners to develop independent modules individually, which reduces the need for formal knowledge transfer between companies [30]. At the same time, modularisation requires the formalisation of the interfaces, which stimulates some degree of functional dependence between partners [15] and generates specialised expertise in the members of the supply chain [31]. These arguments indicate the relevance of modularisation in the automotive industry. This article focuses on the relationship between modularisation, product design, competitiveness, and innovation in the Brazilian automotive industry. In 2016, 31 automakers and their respective supply chains operated in Brazil [32]. Two companies have operated in the modular concept since the 1990s: MAN, a truck manufacturer, and General Motors [33].

The main purpose of this article is to test factors that can contribute to the implementation of a modularisation strategy in the Brazilian automotive industry. The research question we pose is: What factors contribute most to the implementation of a strategy of modularisation in the Brazilian automotive industry? The research method is a survey. The specific objectives are to identify factors that may contribute to the formation of a modularisation strategy in the industry; to model and measure these factors in the Brazilian automotive industry; and to analyse the results according to multivariate statistical techniques.

\section{REVIEW}

Modularisation techniques are present in the design of new products, in manufacturing processes design [12,22], in organisational processes [27,34-36], and in service processes design [37-39]. Modularisation techniques make it easier to plan and control the degree to which changes in customer requirements affect the final product and the manufacturing process. Modularisation techniques also meet new demands faster, since they allow design decisions that are needed for the internal detailing of the parts $[5,40]$ to be postponed until more information is available,.

Modularisation relies on modular architecture or integrated architecture, and has implications that can range from design engineering to business strategy [41]. The modular architecture includes designating specific functions to specific components of the physical structure of the product [42]. In a modular architecture, components communicate themselves using standardised interfaces. The integrated architecture includes the assigning of different functionalities to a single component. In this case, interfaces couple components, reducing the flexibility to recombine functions [43]. Modularisation allows the use of external sources of knowledge and innovation in product and process development processes, accelerating the solutions to meet customers' demands [44].

Modularisation can be useful in developing products that are more competitive and in making manufacturing processes more efficient $[40,45]$ while involving systemic decisions that reciprocally affect both the modules and the process design $[5,46]$. Modularisation can make manufacturing processes more efficient, as it allows a larger variety of products with fewer specific features to be produced at a reduced cost [14]. It can also increase flexibility in production and reduce product development and manufacturing lead-times [41,47]. Jacobs et al. [48] state that modularity in product design is the key factor in describing interrelationships and interactions between product and process modularity. Modularisation design elements can quickly create new products by recombining previously existing modules and processes [6].

Products with a modular architecture can increase flexibility, making manufacturing more responsive to customers' demands [48]. Innovation initiatives can also stimulate modularisation [49]. Development processes relying on modularisation usually require companies to perform experiments based on new ideas. Such experiments can result in products and processes that are faster and cheaper since they usually start from an existing product or process [40]. Modular architectures also allow for independent innovations in modules, with no need for change in an entire product $[15,19,22,29,40]$. By contrast, radical innovations are more difficult to pursue due to the need to 
abandon previous developments totally [50]. The insertion of products developed from modular designs has contributed to the emergence of devices with universal compatibility in important contemporary industries, such as the computer and communication devices industries $[17,40]$.

In short, regarding the relationship with customers, modularity in product design can speed up new product development, reduce development costs, and enhance customisation possibilities, according to consumers' preferences. Regarding the relationship with the manufacturers, modularity in process design can reduce setup times, reduce costs, and enhance revenues of low lot sizes required for customised production [48].

Previous studies have observed that business environments that are prone to innovation have also promoted the use of modularisation $[15,17]$. Specifically, in product design, modular structures are favoured over integrated ones when rapid innovations are more important than performance [51]. Innovation is expected to use modularisation through two mechanisms: innovation within a component or subsystem, and innovation by mix and match of existent modules [52]. The existence of information systems, and the need to outsource activities can also facilitate the modularisation of product design, and so reduce the scope of in-house activities. This kind of organisation requires from the company a specific managerial organisation to comply with the formal requirements of a modularisation strategy.

Finally, companies can respond to volatile markets simply by recombining existent resources and modules, instead of creating entirely new products. The required agility for such recombination is usually provided by a managerial and information structure that is suitable to handle the issues related to modularity along the product life cycle [53]. In complex production networks, technical changes in products strongly influence the managerial processes of companies and partners [54]. Usually, planning and controlling activities related to product changes require an appropriate managerial structure $[55,56]$.

\section{THE RESEARCH}

The research method is a survey [57]. Surveys are useful in research involving innovation, strategies, products, and services [58,59]. The main research techniques are principal component analysis and structural equation modelling by partial least squares (SEM-PLS) [60]. A SEM-PLS model has two levels of analysis: the observation level and the theoretical level. On the observation level, the outer model assesses latent variables, supported by indicators that capture manifest variables. On the theoretical level, the inner model tests relationships among latent variables, which can be endogenous or exogenous [61]. Latent variables connect each other via theoretical meanings, expressed through hypotheses and supported by rationales [62].

Models can be reflective or formative. In reflective models, indicators of the same latent variable are highly correlated, as they are different approaches to reflecting the essence of the same variable. The latent variable causes the indicators, not the reverse, as in formative models [63]. Latent variables connect to manifest variables by factor loadings, which are inferred parameters estimated from empirical associations among the observations of the manifest variables [62]. This study uses only reflective models.

Previous studies help to derive the research hypotheses that support the initial inner model:

- H1: the use of modularisation issues (MOD, latent variable $\xi 1$ ) in design, even isolated, positively influences the creation of a modularisation strategy within the production strategy (MOD_STRT, latent variable $\xi 10$ );

- $\quad$ H2: the potential of modularisation to create a competitive differential (DIF, latent variable $\xi 2$ ) positively influences the creation of a modularisation strategy within the production strategy (MOD_STRT, latent variable $\xi 10$ ); and

- $\quad H 3$ : the existence of an environment prone to innovation in products and processes (INN, latent variable $\xi 3$ ) positively influences the creation of a modularisation strategy within the production strategy (MOD_STRT, latent variable $\xi 10)$. 
Latent variables (henceforward called 'constructs') are reflective, and integrate the inner model, in which three exogenous constructs $(\xi 1, \xi 2, \xi 3)$ influence one endogenous construct $(\xi 10)$. Figure 1 shows the initial inner model, based on the hypotheses.

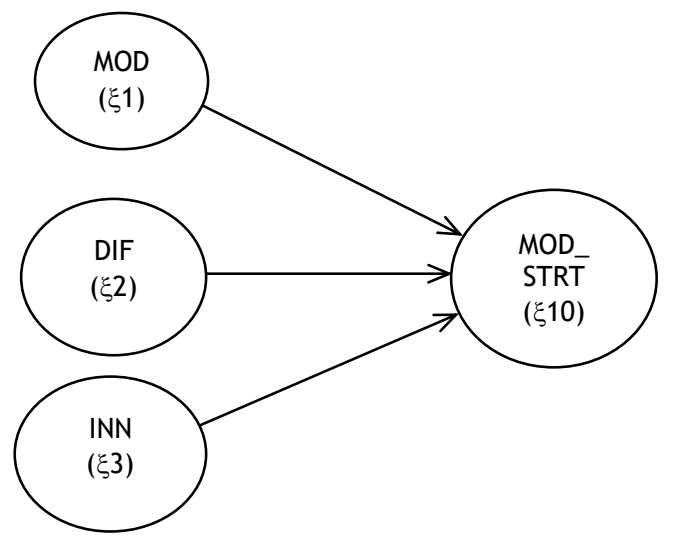

Figure 1: Initial inner model

The survey included thirteen questions that investigated three exogenous constructs: modularisation issues (product architecture, effects on manufacturing, effects on mass customisation, and strategy support); competition (effects on cost, flexibility, delivery, and quality); and innovative environment in the company (business profile, new products, increase of revenue, customer satisfaction). The model also investigated the endogenous construct modularisation strategy in product design. For the survey, we used Google Forms [64]. The respondents used a Likert scale from 1 to 5 , in which 1 represented 'Fully disagree' and 5 represented 'Fully agree', with intermediate degrees of agreement [65].

Previous studies must support the indicators and constructs of an initial theoretical outer model. Eventually, the initial outer model may change after the exploratory factor analysis (EFA). According to the EFA, the indicators may remain unchanged in the model, may exit, or may move among the constructs. Table 1 shows the initial outer model and the relevant literature supporting the manifest variables. All indicators will remain, but some will move after the EFA.

The research focus is on the Brazilian automotive industry. In 2017, 647 companies in the automotive industry ( 31 automakers and 616 auto parts manufacturers) and more than 5,500 dealers operated in Brazil. These companies spanned several business segments, such as automakers (automobiles, light commercial vehicles, trucks, buses, agricultural machinery, and self-propelled road machinery), and first- and second-tier auto parts suppliers, with revenues in 2015 of US\$ 59.1 billion, making up 4.0 per cent of Brazil's gross domestic product (GDP). The industry business yielded more than US\$ 12 billion in taxes and employed more than 1.3 million people in 2015 [32].

Product development engineering managers, engineering directors, and designers answered the questionnaires (34 per cent are development engineers, 66 per cent are managers; 100 per cent are at least undergraduates, 69 per cent are graduates). The total number of valid responses is 117 companies: 19 automakers, 39 first-tier suppliers, and 59 second-tier suppliers. For reflective models, we used a rule of thumb presented by Barclay, Higgins, and Thompson [76]. The minimum sample size must be ten times the largest number of paths directed to a single construct. Since the maximum number of paths running into a single construct is four, the sample suffices. The rate of return was 50.43 per cent. The estimated rate of return is 31 per cent, and 46 per cent in this type of research [58]. Table 2 shows respondents' data for the workforce and gross revenue in 2015, in US currency. 
Table 1: Initial outer model

\begin{tabular}{|c|c|c|c|}
\hline Constructs & Indicators & Subjacent rationale & Authors \\
\hline \multirow[t]{3}{*}{$\begin{array}{l}\text { Modularisation } \\
\text { issues (MOD } \square 1) \text {, } \\
\text { exogenous }\end{array}$} & $\begin{array}{l}\text { Use of modular } \\
\text { architecture in the } \\
\text { early stages of new } \\
\text { product development } \\
\text { (MOD1). }\end{array}$ & $\begin{array}{l}\text { Importance of knowledge and application } \\
\text { of modular architecture prior to the } \\
\text { development of new products. }\end{array}$ & $\begin{array}{l}{[5,15,19,20,2} \\
9,42]\end{array}$ \\
\hline & $\begin{array}{l}\text { Use of integrated } \\
\text { modularisation in the } \\
\text { development of } \\
\text { products and processes } \\
\text { (MOD2). }\end{array}$ & $\begin{array}{l}\text { Importance of the integrated application } \\
\text { of modularisation in the development of } \\
\text { products and processes. }\end{array}$ & $\begin{array}{l}{[15-18,21,46,} \\
67]\end{array}$ \\
\hline & $\begin{array}{l}\text { Use of modularisation } \\
\text { in meeting projects' } \\
\text { requirements (MOD3). }\end{array}$ & $\begin{array}{l}\text { Importance of having the necessary } \\
\text { knowledge to find solutions based on } \\
\text { modularisation. }\end{array}$ & $\begin{array}{l}{[13,14,18,20,} \\
21,23,24,55,6 \\
8]\end{array}$ \\
\hline \multirow[t]{4}{*}{$\begin{array}{l}\text { Competitivity } \\
\text { (DIF } \quad \text { 2), } \\
\text { exogenous }\end{array}$} & $\begin{array}{l}\text { Modularisation can } \\
\text { reduce the cost of } \\
\text { products and increase } \\
\text { market share (DIF1). }\end{array}$ & $\begin{array}{l}\text { Application of modularisation to create a } \\
\text { competitive advantage by reducing costs } \\
\text { and consequently increase market share. }\end{array}$ & $\begin{array}{l}{[17,27,69,28} \\
29,44,66]\end{array}$ \\
\hline & $\begin{array}{l}\text { Modularisation can help } \\
\text { to meet mass } \\
\text { customisation markets' } \\
\text { demands (DIF2). }\end{array}$ & $\begin{array}{l}\text { Application of modularisation to create a } \\
\text { competitive advantage by flexibility and } \\
\text { consequently increase market share in } \\
\text { customised products. }\end{array}$ & {$[13,23-26]$} \\
\hline & $\begin{array}{l}\text { Modularisation } \\
\text { manufactures faster } \\
\text { and reduces } \\
\text { uncertainty in new } \\
\text { products' development } \\
\text { (DIF3). }\end{array}$ & $\begin{array}{l}\text { Application of modularisation to create a } \\
\text { competitive advantage by reducing } \\
\text { average lead-time and variability in new } \\
\text { product development and improve } \\
\text { dependability. }\end{array}$ & $\begin{array}{l}{[7,70,13,14,2} \\
2,47,48,71]\end{array}$ \\
\hline & $\begin{array}{l}\text { Modularisation } \\
\text { simplifies products, } \\
\text { allowing part } \\
\text { replacement (DIF4). }\end{array}$ & $\begin{array}{l}\text { Application of modularisation to create a } \\
\text { competitive advantage by improving } \\
\text { quality and reliability indicators. }\end{array}$ & $\begin{array}{l}{[5,7,15,16,19} \\
, 72,27- \\
29,50,56,67]\end{array}$ \\
\hline \multirow[t]{4}{*}{$\begin{array}{l}\text { Environment } \\
\text { prone to } \\
\text { innovation (INN } \\
\square 3 \text { ), exogenous }\end{array}$} & $\begin{array}{l}\text { The company has an } \\
\text { innovative } \\
\text { management profile } \\
\text { (INN1). }\end{array}$ & $\begin{array}{l}\text { Perception of the degree to which the } \\
\text { company stimulates innovation practices. }\end{array}$ & {$[4,66,73,74]$} \\
\hline & $\begin{array}{l}\text { The company manages } \\
\text { innovation to develop } \\
\text { new products (INN2). }\end{array}$ & $\begin{array}{l}\text { Perception of the degree to which the } \\
\text { need for new products and processes } \\
\text { causes the company to innovate. }\end{array}$ & {$[13,14,66,70]$} \\
\hline & $\begin{array}{l}\text { Innovation contributes } \\
\text { to increase revenue } \\
\text { (INN3). }\end{array}$ & $\begin{array}{l}\text { Perception of the degree to which new } \\
\text { products and processes contribute to } \\
\text { increasing revenue. }\end{array}$ & {$[66,73-75]$} \\
\hline & $\begin{array}{l}\text { Innovation contributes } \\
\text { to meeting customers' } \\
\text { requirements (INN4). }\end{array}$ & $\begin{array}{l}\text { Perception of the degree to which the } \\
\text { company uses innovation to improve } \\
\text { customers' satisfaction. }\end{array}$ & $\begin{array}{l}{[15,16,19,27,} \\
28,50]\end{array}$ \\
\hline \multirow{2}{*}{$\begin{array}{l}\text { Modularisation } \\
\text { strategy within } \\
\text { the production } \\
\text { strategy (INN } \\
\text { व), } \\
\text { endogenous }\end{array}$} & $\begin{array}{l}\text { Existence of a specific, } \\
\text { articulated strategy for } \\
\text { modularisation } \\
\text { activities (R1). }\end{array}$ & $\begin{array}{l}\text { Extension and intensity of articulated } \\
\text { actions promoting modularisation of } \\
\text { products and services along the entire life } \\
\text { cycle. }\end{array}$ & $\begin{array}{l}{[15,17,27,69,} \\
28,29]\end{array}$ \\
\hline & $\begin{array}{l}\text { Existence of a } \\
\text { managerial structure to } \\
\text { handle modularisation } \\
\text { (R2). }\end{array}$ & $\begin{array}{l}\text { Efficiency and extension of the } \\
\text { management activities regarding } \\
\text { modularisation. }\end{array}$ & {$[12,53-56]$} \\
\hline
\end{tabular}


Table 2: Demographic information on the sample

\begin{tabular}{rccc}
\hline Class of company & $\begin{array}{c}\text { Number of } \\
\text { companies }\end{array}$ & $\begin{array}{c}\text { Average revenue } \\
\text { (Billions US\$) }\end{array}$ & $\begin{array}{c}\text { Average } \\
\text { workforce }\end{array}$ \\
\hline Automakers & 19 & 1,160 & 9,500 \\
First-tier & 39 & 185 & 900 \\
Second-tier & 59 & 76 & 430 \\
\hline
\end{tabular}

\section{RESULTS AND ANALYSIS}

Supported by SPSS, we ran the EFA to check the latent structure of the indicators [62]. SPSS performs the Kaiser-Meyer-Olkin (KMO) and Bartlett sphericity tests to verify the adequacy of the sample. KMO produces a value between one and zero. Values above 0.60 suggest that the sample is appropriate [63]. The result was 0.922 . Bartlett's sphericity test evaluates whether each sequential eigenvalue is significantly different from the remaining eigenvalues. Results should show $p<0.05$ [77]. The result was $p=0.00$. Previously reviewed studies provided the indicators of the outer model.

Some of the indicators distributed according to unexpected factors, so we reorganised the constructs [63]. The best-achieved reorganisation relies on the extraction of three factors and the application of the Equamax rotation and Kaiser normalisation. The explained variance is 75.5 per cent of the total variance. Explained variance must exceed 70 per cent [77]. The reorganisation of the constructs and the factors' extraction assured unidimensionality. All loads exceed 0.6 [78]. Therefore all indicators remained in the model. Table 3 shows the EFA result, the old and new acronyms, and keywords to the indicators, which help to understand the new nomenclature of the constructs. Values in bold refer to the same construct.

Table 3: EFA

\begin{tabular}{ccccll}
\hline & & \multicolumn{4}{c}{ Factors } \\
\cline { 3 - 6 } Old acronym & New acronym & 1 & 2 & 3 & keywords \\
\hline MOD1 & Design1 & 0,17 & 0,78 & 0,35 & early stages of development \\
MOD2 & Design2 & 0,23 & 0,64 & 0,56 & integrated modularisation \\
MOD3 & Customer1 & 0,35 & 0,56 & 0,60 & projects' requirements \\
DIF1 & Design3 & 0,07 & 0,64 & 0,51 & increases market share \\
DIF2 & Design4 & 0,39 & 0,74 & 0,17 & mass customisation \\
DIF3 & Customer2 & 0,26 & 0,30 & 0,78 & reduces uncertainty \\
DIF4 & Customer3 & 0,25 & 0,27 & 0,80 & simplifies products \\
INN1 & Innov1 & 0,76 & 0,05 & 0,34 & innovative profile \\
INN2 & Innov2 & 0,81 & 0,39 & 0,08 & innovation and new products \\
INN3 & Innov3 & $\mathbf{0 , 8 2}$ & 0,15 & 0,24 & innovation and revenue \\
INN4 & Innov4 & $\mathbf{0 , 7 8}$ & 0,31 & 0,24 & innovation and customers \\
\hline
\end{tabular}

The three endogenous constructs are design, customers, and innovation.

The 'design' construct refers to the recognition that the company uses modularisation techniques in design. The subjacent rationale [62] of the construct is: the application of modularisation in the early stages of development, the use of integrated modularisation in the products and manufacturing processes, reduced costs and increased market-shares achieved by modularisation, and mass customisation requirements fulfilled by modularisation, indicating that the company uses modularisation in the design phase of new product development. 
The 'customers' construct refers to the recognition that the company uses modularisation techniques to meet customers' requirements. The subjacent rationale of the construct is: the application of modularisation to fulfill projects' requirements, to reduce uncertainty, and to simplify products, indicating that the company uses modularisation to meet customers' requirements.

The 'innovation' construct refers to the recognition of a consistently innovative behaviour. The subjacent rationale of the construct is: an innovative managerial profile, the use of innovative techniques in new products, the existence of revenues due to innovation, and the use of innovation to meet customers' requirements, indicating that the company has a consistent innovative behaviour.

The exogenous construct is 'modularisation strategy'. The rationale is: a specific articulated strategy to deal with modularisation techniques and a managerial structure to handle modularisation activities and their implications, indicating that a company has a modularisation strategy inserted in its operation and production strategy.

Finally, the rationale for the inner model is: if a company uses modularisation in design, uses modularisation in meeting customers' requirements, and has a consistent innovative behaviour, then this company also has a modularisation strategy inserted in its operation and production strategy.

Figure 2 shows the model and the results of the PLS algorithm, calculated by the software SmartPLS $2.0 \mathrm{M} 3[79]$.

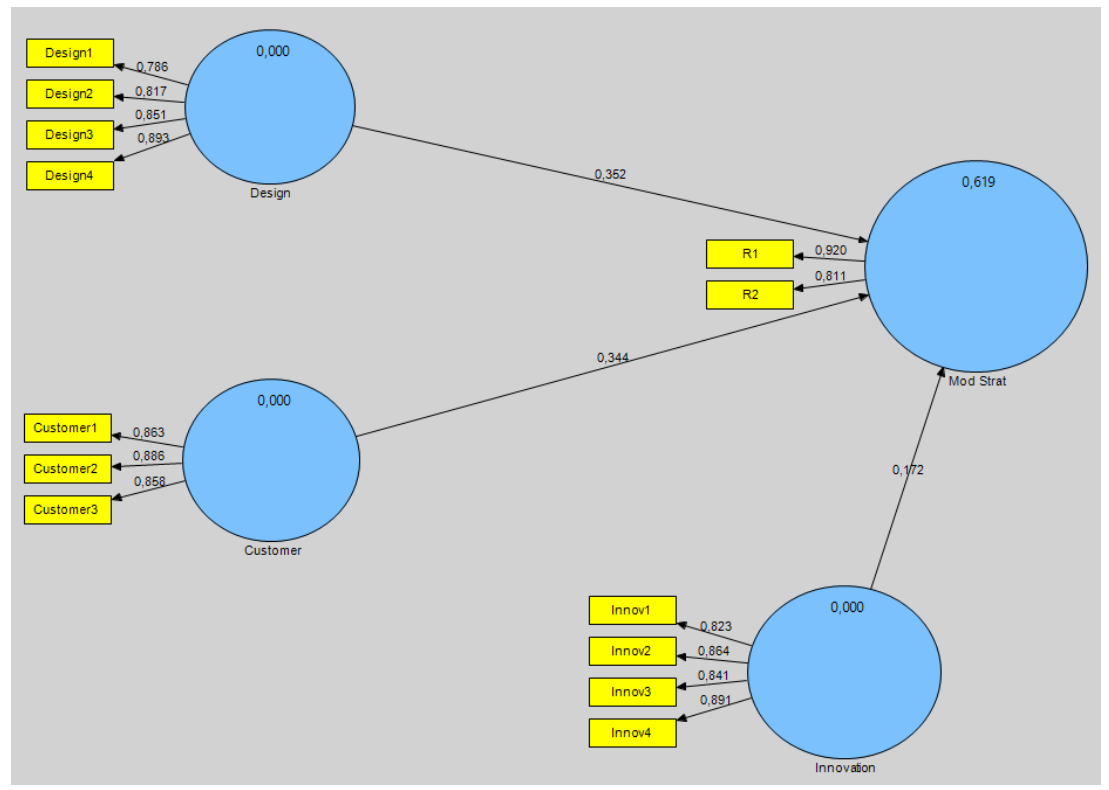

Figure 2: Model calculation

Hair et al. [63] recommend assuring internal consistency reliability, convergent validity, and discriminant validity for a reflective model. For the structural model, they recommend verifying the coefficient of determination, the size and significance of path coefficients, the effect size $f 2$ in the coefficient of determination, and the cross-validated redundancy Q2.

Cronbach's alphas and composite reliabilities can help to verify the internal consistency reliability. The Cronbach's alphas and composite reliabilities for $[\xi 1, \xi 2, \xi 3, \xi 10]$ are $[0.86,0.84,0.88,0.68]$ and $[0.90,0.90,0.89,0.86]$ respectively. Alphas must exceed 0.6 . Composite reliabilities must range from 0.6 to 0.9 in exploratory studies [63].

Average extracted variances (AVE) and outer loadings or indicator reliabilities (the indicator reliability is the square of the outer loading) can verify the convergent validity. The AVEs for [ $\xi 1$, 
$\xi 2, \xi 3, \xi 10]$ are $[0.70,0.75,0.73,0.75]$. AVEs must be larger than 0.5 to confirm convergent validity [78]. All outer loadings are higher than 0.708 (all indicator reliabilities are higher than 0.50 ). Bagozzi, Yi, and Phillips [80] recommend retaining unconditionally indicators with outer loadings higher than 0.708 (reliabilities higher than 0.5 ), removing unconditionally indicators with outer loadings lower than 0.4 (reliabilities lower than 0.16 ), and considering the differences in reliabilities and validities before and after removing indicators with outer loadings in the interval [0.4 - 0.708].

Cross-loadings and AVE can verify the discriminant validity. The reallocation of indicators favoured discriminant validity [81]. For all indicators, the outer loading on the own construct is greater than any cross-loadings, i.e., the loading of the indicator on the other constructs. For discriminant validity, the square root of the AVE should be higher than any correlation among the constructs [82]. Table 4 shows the application of the Fornell-Larcker criterion. In the diagonal, in bold, the table shows the square root of the AVEs.

Table 4: Discriminant validity test

\begin{tabular}{ccccc}
\hline & $\xi 1$ & $\xi 2$ & $\xi 3$ & $\xi 10$ \\
\hline$\xi 1$ & 0.84 & & & \\
$\xi 2$ & 0.83 & 0.87 & & \\
$\xi 3$ & 0.62 & 0.58 & 0.85 & \\
$\xi 10$ & 0.75 & 0.74 & 0.59 & 0.87 \\
\hline
\end{tabular}

For the structural model, the criteria used are the coefficient of determination R2 (the percentage of variance in the endogenous construct explained by the exogenous constructs), path coefficients, effect size f2, and cross-validated redundancy Q2 [78].

$R^{2}$ is 0.792 . As it exceeds 60 per cent, the structural model is consistent [63]. The path coefficients for $[\xi 1 \rightarrow \xi 10 ; \xi 2 \rightarrow \xi 10 ; \xi 3 \rightarrow \xi 10]$ are $[0.352,0.344,0.172]$. Path coefficients have standardised values ranging from -1 to +1 ; the closer to 1 or -1 , the stronger the positive or negative relationship. One method of assessing the significance of the path coefficients is by $t$-values and significance, using the bootstrapping method. Table 5 shows the significance of the path coefficients for $p$-values of 1 per cent and 5 per cent.

Table 5: Significance of path coefficients

\begin{tabular}{|c|c|c|c|c|}
\hline path & $\begin{array}{l}\text { Size of the } \\
\text { coefficient }\end{array}$ & $\begin{array}{c}t \\
\text { statistics }\end{array}$ & $\begin{array}{c}\text { Significance }(p<0.05, \\
\text { one-tailed, critical level } \\
=1.65) ?\end{array}$ & $\begin{array}{l}\text { Significance }(p<0.01, \text { one- } \\
\text { tailed, critical level }=2.33) ?\end{array}$ \\
\hline$\xi 1->\xi 10$ & 0.352 & 2.36 & Yes & Yes \\
\hline$\xi 2->\xi 10$ & 0.344 & 2.30 & Yes & No \\
\hline$\xi 3->\xi 10$ & 0.172 & 1.75 & Yes & No \\
\hline
\end{tabular}

The impact that a single exogenous construct has on an endogenous one is the $\mathrm{f} 2$ effect. To calculate the effect of an exogenous construct, the SEM-PLS algorithm must run twice, with all constructs and without the specific constructs. The larger the difference in R2, the more influence the construct has. Cohen [83] states that values around $0.35,0.15$, and 0.02 respectively represent large, medium, and small effect sizes. Equation 1 provides the f2 effect size [63]. Table 6 shows the f2 effect.

$$
f^{2}=\frac{R_{\text {included }}^{2}-R_{\text {excluded }}^{2}}{1-R_{\text {included }}^{2}}
$$


Table 6: $f^{2}$ effect size

\begin{tabular}{rccc}
\hline Structural model & $R^{2}$ & $f^{2}$ & Effect size \\
\hline All $\xi$ included & 0,619 & & \\
without $\xi 1$ & 0,586 & 0,09 & Medium \\
without $\xi 2$ & 0,583 & 0,10 & Medium \\
without $\xi 3$ & 0,608 & 0,03 & Small \\
\hline
\end{tabular}

Finally, the Q2 value indicates the model's predictive relevance for an endogenous construct - that is, the model's out-of-the-sample predictive power. A Q2 larger than zero for an endogenous reflective construct means that the model exhibits predictive relevance. Otherwise, it lacks predictive relevance. The calculation of Q2 requires the blindfolding procedure. As with $\mathrm{f} 2$, the q2 effect size is calculated by omitting the constructs one by one. The resulting q2 effect size serves to classify the relevance of the endogenous construct. Calculated with an equation similar to Equation 1 , values around $0.02,0.15$, and 0.35 imply small, medium, or large predictive relevance [78]. Table 7 shows the q2 effect in the measurement model.

Table 7: $q^{2}$ effect size

\begin{tabular}{cccc}
\hline Structural model & $Q^{2}$ & $q^{2}$ & Effect size \\
\hline All $\xi$ included & 0.451 & & \\
without $\xi 1$ & 0.416 & 0.064 & Medium \\
without $\xi 2$ & 0.429 & 0.040 & Small \\
without $\xi 3$ & 0.420 & 0.056 & Medium \\
\hline
\end{tabular}

Combining the various criteria, we conclude heuristically that all constructs are relevant, but that $\xi 1$ and $\xi 2$ are more relevant than $\xi 3$. The relevance means that, in Brazil's automotive industries, companies are more prone to formalise a modularisation strategy if they already have some initiatives in the design phase and if they are concerned about creating a competitive differential, than if they simply have an innovative business environment.

\section{CONCLUSION}

Our study concludes that, in the Brazilian automotive industry, all the studied factors contribute to the implementation of a modularisation strategy. However, the degree of contribution varies according to the factor. Variables connected to the design of the product are more influential than variables connected to the fulfilment of customers' requirements, and both are more influential than innovation. Albeit to a lesser extent, the pre-existence of a business environment that favours innovation should also be considered in further studies.

This study has implications for engineering management and product strategy practices, especially in the automotive industry. If managers want to create or increase the use of modularisation in the industry, they have two good options. The first is to use modularisation techniques, even isolated or non-articulated, with process modularisation from the initial phase - the design of the product. The second is to try to fulfil customers' requirements with the use of modularisation techniques, instead of other methods. As the literature reports, the inclusion of modular architecture in the product is relevant to promote an articulated strategy that includes a systemic adoption of modularisation. It is also remarkable that the average scores (retrieved from the questionnaires) of the constructs 'design' and 'customer' (which have more influence) do not differ much (3.9 and 3.6 respectively), but both are less than the score of innovation (4.08), which has less influence. The difference indicates that the hierarchy of intensities and capacities to influence are different, meaning that, in a general sense, the industry does not pursue a modularisation strategy - or, at least, does not have a roadmap to do it. Further research using different methodologies such as action research is necessary to confirm a road map to modularisation. 
For further research, we suggest a confirmatory replication. Eventually, new studies should consider the inclusion of a new construct for correlated technologies, such as flexible manufacturing and automation. Finally, we suggest the replication with the same sample over time, to show the evolution of the factors in the Brazilian automotive industry.

\section{REFERENCES}

[1] Teece, D.J. 2010. Business models, business strategy and innovation. Long Range Planning, 43(1), pp. 72 94. doi:10.1016/j.trp.2009.07.003.

[2] Artz, K.W., Norman, P.M., Hatfield, D.E. \& Cardinal, L.B. 2010. A longitudinal study of the impact of R\&D, patents, and product innovation on firm performance. J. Prod. Innov. Manag., 27(5), pp. 725-740. doi:10.1111/j.1540-5885.2010.00747.x.

[3] Klepper, S. 1996. Entry, exit, growth, and innovation over the product life cycle. Am. Econ. Rev. 86(3), pp. $562-583$.

[4] Crossan, M.M. \& Apaydin, M. 2010. A multi-dimensional framework of organizational innovation: A systematic review of the literature. J. Manag. Stud., 47(6), pp. 1154-1191. doi:10.1111/j.14676486.2009.00880.x.

[5] Ulrich, K. 1995. The role of product architecture in the manufacturing firm. Res. Policy, 24(3), pp. 419440. doi:10.1016/0048-7333(94)00775-3.

[6] Sanchez, R. \& Mahoney, J.T. 1996. Modularity, flexibility, and knowledge management in product and organization design. Strateg. Manag. J., 17(1), pp. 63-76.

[7] Robertson, D. \& Ulrich, K. 1998. Planning for product platforms. Sloan Manag. Rev., 39(1), pp. 19-31. doi:Article.

[8] Krishnan, V. \& Ulrich, K.T. 2001. Product development decisions: A review of the literature. Manage Sci., 47(1), pp. 1-21. doi:10.1287/mnsc.47.1.1.10668.

[9] Lau, A.K.W., Yam, R.C.M. \& Tang, E.P.Y. 2010. Supply chain integration and product modularity: An empirical study of product performance for selected Hong Kong manufacturing industries. Int. J. Oper. Prod. Manag., 30(1), pp. 20-56. doi:10.1108/01443571011012361.

[10] Huang, C.C., Liang, W.Y., Chuang, H.F. \& Chang, Z.Y. 2012. A novel approach to product modularity and product disassembly with the consideration of 3R-abilities. Comput. Ind. Eng., 62(1), pp. 96-107. doi:10.1016/j.cie.2011.08.021.

[11] He, D.W. \& Kusiak, A. 1997. Design of assembly systems for modular products. IEEE Trans. Robot Autom. 13(5), pp. 646-55. doi:10.1109/70.631226.

[12] Nunes, F.L., Vaccaro, G.L.R. \& Antunes Júnior, J.A.V. 2017. The development of the Hyundai production system: The historical evolution. J. Manuf. Syst. 43(1), pp. 47-57. doi:10.1016/j.jmsy.2017.02.003.

[13] Gershenson, J.K., Prasad, G.J. \& Zhang, Y. 2003. Product modularity: Definitions and benefits. J. Eng. Des., 14(3), pp. 295-313. doi:10.1080/0954482031000091068.

[14] Shamsuzzoha, A.H.M. 2011. Modular product architecture for productivity enhancement. Bus. Process. Manag. J., 17(1), pp. 21-41. doi:10.1108/14637151111105562.

[15] Ethiraj, S.K. \& Levinthal, D. 2004. Modularity and innovation in complex systems. Manage. Sci., 50(2), pp. 159-173. doi:10.1287/mnsc. 1030.0145.

[16] Chesbrough, H. \& Prencipe, A. 2008. Networks of innovation and modularity: A dynamic perspective. Int. J. Technol. Manag., 42(4), pp. 414-425. doi:10.1504/IJTM.2008.019383.

[17] Ethiraj, S.K., Levinthal, D. \& Roy, R.R. 2008. The dual role of modularity: Innovation and imitation. Manage. Sci., 54(5), pp. 939-955. doi:10.1287/mnsc.1070.0775.

[18] Vickery, S.K., Koufteros, X., Dröge, C. \& Calantone, R. 2015. Product modularity, process modularity, and new product introduction performance: Does complexity matter? Prod. Oper. Manag., 25(4), pp. 75170. doi:10.1017/CBO9781107415324.004.

[19] Henderson, R.M. \& Clark, K.B. 1990. Architectural innovation: The reconfiguration of existing product technologies and the failure of established firms. Adm. Sci. Q., 35(1), pp. 9-30.

[20] Doran, D., Hill, A., Hwang, K.-S. \& Jacob, G. 2007. Supply chain modularisation: Cases from the French automobile industry. Int. J. Prod. Econ., 106(1), pp.2-11. doi:10.1016/j.ijpe.2006.04.006.

[21] Danese, P. \& Filippini, R. 2010. Modularity and the impact on new product development time performance. Int. J. Oper. Prod. Manag. 30(11), pp. 1191-209. doi: 10.1108/01443571011087387.

[22] Piran, F.A.S., Lacerda, D.P., Camargo, L.F.R., Viero, C.F., Teixeira, R. \& Dresch, A. 2016. Product modularity and its effects on the production process: An analysis in a bus manufacturer. Int. J. Adv. Manuf. Technol. 88(5-8), 2331-2343. doi:10.1007/s00170-016-8906-8.

[23] Duray, R., Ward, P.T., Milligan, G.W. \& Berry, W.L. 2000. Approaches to mass customization: Configurations and empirical validation. J. Oper. Manag., 18(6), pp. 605-25. doi:10.1016/S02726963(00)00043-7.

[24] Mikkola, J.H. 2007. Management of product architecture modularity for mass customization: Modeling and theoretical considerations. IEEE Trans. Eng. Manag., 54(1), pp. 57-69. doi:10.1109/TEM.2006.889067.

[25] Scavarda, L.F., Reichhart, A., Hamacher, S. \& Holweg, M. 2010. Managing product variety in emerging markets. Int. J. Oper. Prod. Manag., 30(2), pp. 205-224. doi:10.1108/01443571011018716. 
[26] Pollard, D., Chuo, S. \& Lee, B. 2008. Strategies for mass customization. J. Bus. Econ. Res., 6(7), pp. 7786.

[27] Langlois, R.N. \& Robertson, P.L. 1992. Networks and innovation in a modular system: Lessons from the microcomputer and stereo component industries. Res. Policy., 21(2), pp. 297-313. doi:10.1016/00487333(92)90030-8.

[28] Argyres, N. \& Bigelow, L. 2010. Innovation, modularity, and vertical deintegration: Evidence from the early U.S. auto industry. Organ. Sci., 21(4), pp. 842-853. doi:10.1287/orsc.1090.0493.

[29] Ozman, M. 2011. Modularity, industry life cycle and open innovation. J. Technol. Manag. Innov., 6(1), pp. 26-37. doi:10.4067/S0718-27242011000100003.

[30] Schulze, A., Brojerdi, G. \& Von Krogh, G. 2014. Those who know, do. Those who understand, teach: Disseminative capability and knowledge transfer in the automotive industry. J. Prod. Innov. Manag., 31(1), pp.79-97. doi:10.1111/jpim.12081.

[31] MacDuffie, J.P. 2013. Modularity-as-property, modularization-as-process, and modularity-as-frame: Lessons from product architecture initiatives in the global automotive industry. Glob. Strateg. J., 3(1), pp. 8-40. doi:10.1111/j.2042-5805.2012.01048.x.

[32] Anfavea. 2017. Brazilian automotive industry yearbook. Associação Nacional dos Fabricantes de Veículos Automotores. São Paulo, Brazil, doi:10.1017/CBO9781107415324.004.

[33] Pandremenos, J., Paralikas, J., Salonitis, K. \& Chryssolouris, G. 2009. Modularity concepts for the automotive industry: A critical review. CIRP J. Manuf. Sci. Technol., 1(1), pp.148-152. doi:10.1016/j.cirpj.2008.09.012.

[34] Salerno, M.S. \& Dias, A.V.C. 1999. Product design modularity, modular production, modular organization: The evolution of modular concepts. Actes Du GERPISA, 33(1), pp. 62-73.

[35] Hoetker, G. 2006. Do modular products lead to modular organizations? Strateg. Manag. J., 27(6), pp. 50118. doi:10.1002/smj.528.

[36] Cheng, L.-C.V. 2011. Assessing performance of utilizing organizational modularity to manage supply chains: Evidence in the US manufacturing sector. Int. J. Prod. Econ., 131(2), pp. 736-746. doi:10.1016/j.ijpe.2011.02.023.

[37] Geum, Y., Lee, S., Kang, D. \& Park, Y. 2011. The customisation framework for roadmapping productservice integration. Serv. Bus., 5(3), pp. 213-236. doi:10.1007/s11628-011-0111-0.

[38] Bask, A., Lipponen, M., Rajahonka, M. \& Tinnilä, M. 2010. The concept of modularity: Diffusion from manufacturing to service production. J. Manuf. Technol. Manag., 21(3), pp. 355-375. doi:10.1108/17410381011024331.

[39] Bask, A., Lipponen, M., Rajahonka, M. \& Tinnilä, M. 2011. Framework for modularity and customization: Service perspective. J. Bus. Ind. Mark., 26(3), pp. 306-319. doi:10.1108/08858621111144370.

[40] Mikkola, J.H. \& Gassmann, O. 2003. Managing modularity of prodict architectures: Toward an integrated theory. Trans. Eng. Manag., 50(1), pp. 1-15.

[41] Brun, A. \& Zorzini, M. 2009. Evaluation of product customization strategies through modularization and postponement. Int. J. Prod. Econ., 120(1), pp. 205-220. doi:10.1016/j.ijpe.2008.07.020.

[42] Borjesson, F. \& Hölttä-Otto, K. 2014. A module generation algorithm for product architecture based on component interactions and strategic drivers. Res. Eng. Des., 25(1), pp. 31-51. doi:10.1007/s00163-0130164-2.

[43] Hölttä, K.M.M. \& Otto, K.N. 2005. Incorporating design effort complexity measures in product architectural design and assessment. Des. Stud., 26(5), pp. 463-485. doi:10.1016/j.destud.2004.10.001.

[44] Cabigiosu, A., Zirpoli, F. \& Camuffo, A. 2013. Modularity, interfaces definition and the integration of external sources of innovation in the automotive industry. Res. Policy, 42(5), pp. 662-675. doi:10.1016/j.respol.2012.09.002.

[45] Kusiak, A. 2002. Integrated product and process design: A modularity perspective. J. Eng. Des., 13(3), pp. 223-231. doi:10.1080/09544820110108926.

[46] Salvador, F., Forza, C. \& Rungtusanatham, M. 2002. Modularity, product variety, production volume, and component sourcing: Theorizing beyond generic prescriptions. J. Oper. Manag., 20(5), pp. 549-575. doi:10.1016/S0272-6963(02)00027-X.

[47] Carnevalli, J.A., Cauchick Miguel, P.A. \& Salerno, M.S. 2012. Survey research on the application of modularity in the automotive industry in Brazil. Production, 23(2), pp. 329-344. doi:10.1590/5010365132012005000040 .

[48] Jacobs, M.A., Jacobs, M., Droge, C., Vickery, S.K. \& Calantone, R. 2011. The effect of product and process modularity on agility and firm growth performance. J. Prod. Innov. Manag., 28(1), pp. 123-137.

[49] Smith, S. \& Yen, C.C. 2010. Green product design through product modularization using atomic theory. Robot Comput. Integr. Manuf., 26(6), pp. 790-79. doi:10.1016/j.rcim.2010.05.006.

[50] Fleming, L. \& Sorenson, O. 2003. Navigating the technology landscape of innovation. MIT Sloan Manag. Rev., 44(1), pp. 15-23.

[51] Smith, R.P. \& Morrow, J. 1999. Product development process modeling. Des. Stud., 20(2), pp. 237-261. doi:10.1016/S0142-694X(98)00018-0.

[52] Schilling, M.A., Steensma, H.K., Sy, W., Henderson, J., Hippie, S., Gray, W., et al. 2001. The use of modular organizational forms: An industry-level analysis, Acad. Manage. J. 44(6), pp. 1149-68.

[53] Galunic, D.C. \& Eisenhardt, K.M. 2001. Architectural innovation and modular corporate forms. Acad. Manag. J., 44(6), pp. 1229-1249. doi:10.2307/3069398. 
[54] Sellitto, M.A., Pereira, G.M., Borchardt, M., Da Silva, R.I. \& Viegas, C.V. 2015. A SCOR-based model for supply chain performance measurement: Application in the footwear industry. Int. J. Prod. Res., 53(16), pp. 4917-4926. doi:10.1080/00207543.2015.1005251.

[55] Doran, D. 2003. Supply chain implications of modularization. Int. J. Oper. Prod. Manag., 23(3), pp. 316326. doi:10.1108/01443570310462785.

[56] Caridi, M., Pero, M. \& Sianesi, A. 2012. Linking product modularity and innovativeness to supply chain management in the Italian furniture industry. Int. J. Prod. Econ., 136(1), pp. $207-217$. doi:10.1016/j.ijpe.2011.11.012.

[57] Forza, C. 2002. Survey research in operations management: A process-based perspective. Int. J. Oper. Prod. Manag., 22(2), pp. 152-194. doi:10.1108/01443570210414310.

[58] Sheehan, K.B. 2001. E-mail survey response rates: A review. J. Comput. Commun., 6(2), retrieved from http://jcmc.indiana.edu/vol6/ issue2/sheehan.html.

[59] Robb, D. \& Xie, B. 2003. A survey of manufacturing strategy and technology in the Chinese furniture industry. Eur. Manag. J., 21(4), pp. 484-496. doi:10.1016/S0263-2373(03)00079-3.

[60] Hulland, J. 1999. Use of partial least squares (PLS) in strategic management research: A review of four recent studies. Strateg. Manag. J., 20(2), pp. 195-1999. doi:10.1007/s13398-014-0173-7.2.

[61] Tenenhaus, M., Vinzi, V.E., Chatelin, Y.M. \& Lauro, C. 2005. PLS path modeling. Comput. Stat. Data Anal., 48(1), pp. 159-205. doi:10.1016/j.csda.2004.03.005.

[62] Bagozzi, R.P. \& Yi, Y. 2012. Specification, evaluation, and interpretation of structural equation models. J. Acad. Mark. Sci., 40(1), pp. 8-34. doi:10.1007/s11747-011-0278-x.

[63] Hair, J.F., Black, W.C., Babin, B.J., Anderson, R.E. \& Tatham, R.L. 2013. Multivariate data analysis. Pearson Education Ltd. London: UK.

[64] Fan, W. \& Yan, Z. 2010. Factors affecting response rates of the web survey: A systematic review. Comput. Human Behav., 26(1), pp. 132-139. doi:10.1016/j.chb.2009.10.015.

[65] Menezes, L.S., Sellitto, M.A., Librelato, T.P., Borchardt, M. \& Pereira, G.M. 2016. Identification and quantification of influent factors in perceived quality of the e-service provided by a university. Bus. Process Manag. J., 22(3), pp. 438-457. doi:10.1108/BPMJ-07-2015-0100.

[66] Sellitto, M.A. \& Luchese, J. 2018. Systemic Cooperative Actions among Competitors: the Case of a Furniture Cluster in Brazil. Journal of Industry, Competition and Trade, 18(4), pp. 513-528. doi:10.1007/s10842-018-0272-9.

[67] Sanchez, R. \& Mahoney, J.T. 1996. Modularity, flexibility, and knowledge management in product and organization design. Strateg. Manag. J., 17(1), pp. 63-76. doi:10.2307/2486991.

[68] Fixson, S.K. 2007. Modularity and commonality research: Past developments and future opportunities. Concurr. Eng., 15(1), pp. 85-111. doi:10.1177/1063293X07078935.

[69] Pil, F.K. \& Cohen, S.K. 2006. Modularity: Implications for imitation, innovation, and sustained advantage. Acad. Manag. Rev., 31(4), pp. 995-1011. doi:10.5465/AMR.2006.22528166.

[70] Newcomb, P.J., Bras, B. \& Rosen, D.W. 1996. Implications of modularity on product design for the life cycle. Proc. 1996 ASME Des. Eng. Tech. Conf. Comput. Eng. Conf., pp.1-12. doi:10.1115/1.2829177.

[71] Erixon, O.G. \& Ericsson, A. 1999. Controlling design variants: Modular products platforms. Society of Manufacturing Engineers. Dearborn, MI: USA.

[72] Saueressig, G.G., de Paris, A., Bauer, J.M., Luchese, J., Sellitto, M.A., \& Antunes Jr., J.A.V. 2017. Strategic Materials Positioning Matrix: an Application in the Automotive Industry in Southern Brazil. International Journal of Industrial Engineering and Management. 8(2), pp. 77-89.

[73] Bloom, N., Draca, M. \& Van Reenen, J. 2016. Trade induced technical change? The impact of Chinese imports on innovation, IT and productivity. Rev. Econ. Stud., 83(1), pp. 87-117.

[74] Savrul, M. \& Incekara, A. 2015. The effect of R\&D intensity on innovation performance: A country level evaluation. Procedia - Soc. Behav. Sci., 210(1), pp. 388-396. doi:10.1016/j.sbspro.2015.11.386.

[75] Sellitto, M.A., Luchese, J., Bauer, J.M., Saueressig, G.G., \& Viegas, C.V. 2017. Ecodesign Practices in a Furniture Industrial Cluster of Southern Brazil: From Incipient Practices to Improvement. Journal of Environmental Assessment Policy and Management, 19(1), 1750001. doi:10.1142/S1464333217500016.

[76] Barclay, D., Higgins, C. \& Thompson, R. 1995. The partial least squares approach to causal modeling, personal computing adoption and use as an illustration. Technol. Stud., 2(2), pp. 285-309.

[77] Hair, J.F., Ringle, C.M. \& Sarstedt, M. 2011. PLS-SEM: Indeed a silver bullet. Journal of Marketing theory and Practice. 19(1), pp. 139-51.

[78] Hair, J.F., Hult, G.T.M., Ringle, C. \& Sarstedt, M. 2016. A primer on partial least squares structural equation modeling (PLS-SEM). Sage Publications, Thousand Oaks, CA: USA.

[79] Ringle, C.M., Wende, S. \& Becker, J.-M. 2015. Smartpls 3. Bönningstedt: SmartPLS. Available at: http: / / forum.smartpls.com/viewtopic.php?f=10\&t=280 (accessed July 2016).

[80] Bagozzi, R.P., Yi, Y. \& Phillips, L.W. 1991. Assessing construct validity in organizational research. Adm. Sci. Q., 36(3), p. 421. doi:10.2307/2393203.

[81] Henseler, J., Ringle, C.M. \& Sarstedt, M. 2014. A new criterion for assessing discriminant validity in variance-based structural equation modeling. J. Acad. Mark. Sci., 43(1), pp. 115-135. doi:10.1007/s11747014-0403-8.

[82] Fornell, C. \& Larcker, D.F. 1981. Evaluating structural equation models with unobservable variables and measurement error. J. Mark. Res., 18(1), p. 39-50. doi:10.2307/3151312.

[83] Cohen, J. 1992. Quantitative methods in psychology. Psychol. Bull., 112(1), pp. 155-159. doi:10.1037/0033-2909.112.1.155. 